\title{
Can Price Transparency Contribute to More Affordable Patient Access to Medicines?
}

\author{
Sabine $\operatorname{Vogler}^{1}$ (D) Kenneth R. Paterson $^{2}$
}

Published online: 3 May 2017

(c) The Author(s) 2017. This article is an open access publication

\begin{abstract}
Affordable patient access to medicines, particularly to new premium-priced medicines, is an issue, even in high-income countries. The pharmaceutical industry has argued in favour of price discrimination amongst countries based on confidential discounts as a solution to ensuring affordability and availability in less-resourced countries. In this editorial, we explain why we disagree, and we elaborate on why price transparency can contribute to affordable patient access to medicines.
\end{abstract}

\section{Current Situation}

Non-availability, non-affordability and delayed market launch of medicines are issues that are not limited to lowand middle-income countries. Public payers and programmes in Australia, Canada, Member States of the EU, the USA and New Zealand have increasingly been struggling with ensuring affordable access to medicines for their patients. Despite their willingness to pay, small high-income countries were not offered some of the new medicines [1]. In countries with lower medicine price levels (such as Greece, Spain or Portugal), medicines were sometimes brought to the market months or years after their first launch, typically in Germany [2]. Medicine prices vary significantly globally, and the differences do not

Sabine Vogler

sabine.vogler@goeg.at

1 WHO Collaborating Centre for Pharmaceutical Pricing and Reimbursement Policies, Pharmacoeconomics Department, Gesundheit Österreich GmbH (GÖG/Austrian Public Health Institute), Vienna, Austria

2 University of Glasgow, Glasgow, Scotland, UK necessarily reflect the economic situation of the purchasing country [3]. The additional therapeutic benefit of some new medicines is not as high as expected or desired and may not justify premium prices $[4,5]$.

In almost all European high-income countries, the prices of new medicines in other European countries are considered, to some extent, in pharmaceutical price setting in the index country. This so-called external price referencing (EPR) policy is, particularly in the case of new, high-cost medicines, frequently supported by evidence generation and assessment (e.g. through health technology assessments) and individual negotiations and agreements on products between payers and the pharmaceutical industry [6]. While these managed-entry agreements can take different forms, such as price-volume agreements, risk-sharing agreements, conditional reimbursement or coverage with evidence development, they have all in common that their contents are usually confidential [7].

\section{Arguments Against and in Favour of Price Transparency}

There is agreement amongst stakeholders about the contribution of EPR to possible availability issues: in settings of widespread use of EPR (such as the case in Europe), this policy incentivizes marketing authorisation holders to first launch a product in countries with higher medicine price levels and to delay market entry, or not market at all, in lower-priced countries [8,9]. This is done to avoid a lowering of the average price level. It is also acknowledged by some parties that pricing based solely on EPR is not fair since it does not consider the economic wealth of a country. 
The pharmaceutical industry's argument, though, that price discrimination through confidential discounts (sometimes wrongfully labelled as 'differential pricing') would be a key solution to ensure affordable access for lower-resourced countries included in the cross-referencing landscape is not unanimously shared. The argument is as follows: Given the widespread use of EPR, the pharmaceutical industry cannot offer medicines at lower list prices to poorer countries, since this would negatively impact prices in more affluent countries that reference to these countries. However, confidential discounts can allow the industry to provide medicines to poorer countries (in which they might not otherwise be available) without reducing the list price against which other countries will reference [10].

We do not accept this argument. The combination of EPR and confidential discounts is common practice in many countries (well-resourced as well as less-resourced), but affordable access has not yet improved for less-resourced countries (as observed in Central and Eastern Europe) [11]. We do not understand why the actual prices paid need to remain confidential. We acknowledge that publicly accessible discounts could encourage policy makers to reference to discounted prices to achieve lower prices in their own countries, and this would reduce profits for the pharmaceutical industry. However, even without disclosure of discounts, payers could have lower prices if they changed the methodology of their EPR policy and decided to reference to published list prices reduced by a certain percentage (i.e. making an assumption of a discount). Reasoning based on solely financial implications under EPR may not adequately reflect the full picture.

We argue for transparency in medicine price deals. This is guided by our understanding that partners in a negotiation should meet on equal terms. Policy makers and purchasers frequently report they feel pressurised into accepting conditions and prices they consider unfavourable (or where they are uncertain about how favourable the deal or offer is) because they want to achieve access to new medicines for their patients (Focus group discussion with policy makers members of the Pharmaceutical Pricing and Reimbursement Information/PPRI network, 20 November 2014).

Current pharmaceutical price negotiations are an example of information asymmetry-a situation where one party to the transaction has more complete and better information than the other party. Multinational companies acting globally meet purchasers that act nationally, or regionally, or as single entities (e.g. hospitals that procure individually). The current organisation of the healthcare system in many countries (different funding responsibilities between outpatient and inpatient sectors, and between federal, regional and local levels) is characterized by fragmentation, and this has weakened the purchasing power of the procurers. During the Pharmaceutical Pricing and Reimbursement Information (PPRI) conference 2015, a high-level pharmaceutical industry representative criticized public procurers: "Despite being monopsonists, you are not good purchasers." [12].

\section{Options for the Future}

One practical approach for procurers to, at least partially, overcome the lack of transparency and information asymmetry, and thus enhance purchasing power, would be increased collaboration amongst procurers. This could also benefit suppliers in terms of reduced transaction costs since they would not need to separately negotiate with each purchaser. However, if pharmaceutical companies attribute higher value to the information asymmetry that strengthens their negotiating position than to lower transaction costs, they would likely oppose collaboration of competent authorities (such as the recently launched Beneluxa collaboration of Belgium, the Netherlands, Luxembourg and Austria, or the Nordic Forum in Europe [13]). Whether pharmaceutical industry opposition to such collaboration should prevent it from happening is an open question.

Interestingly, some reluctance towards collaboration and sharing of information has also been expressed by procurers, each of whom is convinced (or has been persuaded to believe) that they have made 'the best deal', suppliers telling them that they have achieved the most favourable conditions and pricing in return for not disclosing them. Given the prevailing confidentiality, it is difficult to prove the contrary! Few studies have reported on actual discounted prices. Research on discounts for hospitals in five European countries showed that Norway, a country with joint procurement for public hospitals and disclosed discounts, was able to achieve the best conditions, whereas hospitals in the other countries were granted no, or smaller, discounts that did not differ between hospitals [14, 15]. A recent study on list prices and discounted prices for oncology medicines in 15 European countries showed that hospitals in Central and Eastern European countries were granted smaller, or no, discounts compared with the discounts in Italy and Spain for the same medicines [16].

Today, policy makers are, in general, aware that the acceptance of confidential discounts can negatively impact procurement and price negotiation in other health systems. However, since they are responsible primarily for their own budgets and expenditure, they must prioritize and will hence accept discounts and rebates that are only granted on a confidential basis, because they consider them beneficial from their local healthcare perspective [17]. It would be naive to expect policy makers and payers to disclose confidential price deals, thus violating contractual obligations and possibly making future similar deals less likely. They may be 
in a form of a 'prisoner's dilemma' created by the confidential price negotiations, in which the cooperation that could ultimately benefit all payers in the long term may well bring short-term disadvantage to individual payers [2, 17]. It would be equally naïve to expect the pharmaceutical industry to push for price transparency and thus weaken their negotiating position and power. Pharmaceutical companies contribute to medical advances by producing needed medicines, but, in business terms, their shareholders expect them to maximize profits and would view any weakening of their commercial position adversely.

There is an urgent need for affordable patient access to essential medicines the world over. Price discrimination through confidential discounts from industry has not contributed to better affordability and availability, and may have quite contrary effects. Economic theory, and evidence from a few real-life cases, suggests that price transparency supports better-informed decisions and thus improves the negotiating position of purchasers. We encourage policy makers to implement collaborative action leading to a disclosure of actual prices paid. While this may cause some short-term 'pain' in terms of reduced industry willingness to offer discounted prices, we believe that the longer term 'gain' from reducing the information asymmetry and producing a more level playing field for negotiation between payers and industry would justify any short-term downside. Possible options could include legislative measures (to force disclosure of actual prices), informal agreements amongst several purchasers to share prices of selected premium-priced medicines and even possible formal joint procurement. We would, in the interim, like to see more empirical examples to support our assumption that greater price transparency is able to contribute to more affordable patient access.

\section{Compliance with Ethical Standards}

Funding No funding was received for writing this article.

Conflict of interest SV and KP have no conflicts of interest to declare. All authors submitted a signed conflicts of interest disclosure form.

Open Access This article is distributed under the terms of the Creative Commons Attribution-NonCommercial 4.0 International License (http://creativecommons.org/licenses/by-nc/4.0/), which permits any noncommercial use, distribution, and reproduction in any medium, provided you give appropriate credit to the original author(s) and the source, provide a link to the Creative Commons license, and indicate if changes were made.

\section{References}

1. Kanavos P, Vandoros S, Irwin R, Nicod E, Casson M. Differences in costs of and access to pharmaceutical products in the EU. Brussels: European Parliament; 2011.
2. Vogler S, Lepuschütz L, Schneider P, Stühlinger V. Study on enhanced cross-country coordination in the area of pharmaceutical product pricing. Luxembourg: Gesundheit Österreich Forschungs- und Planungs $\mathrm{GmbH}$; Publications Office of the European Commission; 2016.

3. Iyengar S, Tay-Teo K, Vogler S, Beyer P, Wiktor S, de Joncheere $\mathrm{K}$, et al. Prices, costs, and affordability of new medicines for hepatitis C in 30 countries: an economic analysis. PLoS Med. 2016;13(5):e1002032.

4. Carone G, Schwierz C, Xavier A. Cost-containment policies in public pharmaceutical spending in the EU. Brussels: European Commission, Directorate-General for Economics and Financial Afairs; 2012

5. Fojo T, Grady C. How much is life worth: cetuximab, non-small cell lung cancer, and the $\$ 440$ billion question. J Natl Cancer Inst. 2009;101(15):1044-8.

6. Vogler S, Paris V, Ferrario A, Wirtz VJ, de Joncheere K, Schneider $\mathrm{P}$, et al. How can pricing and reimbursement policies improve affordable access to medicines? Lessons learned from european countries. Appl Health Econ Health Policy. doi:10. 1007/s40258-016-0300-z (Epub 6 Jan 2017).

7. Ferrario A, Kanavos P. Managed entry agreements for pharmaceuticals: the European experience. Brussels: EMINet; 2013.

8. Danzon PM, Wang YR, Wang L. The impact of price regulation on the launch delay of new drugs-evidence from twenty-five major markets in the 1990s. Health Econ. 2005;14(3):269-92.

9. Kyle MK. Pharmaceutical price controls and entry strategies. Rev Econ Stat. 2007;89(1):88-99.

10. Towse A, Pistollato M, Mestre-Ferrandiz J, Khan Z, Kaura S, Garrison L. European Union pharmaceutical markets: a case for differential pricing? Int J Econ Bus. 2015;22(2):263-75.

11. Kaló Z, Annemans L, Garrison LP. Differential pricing of new pharmaceuticals in lower income European countries. Expert Rev Pharmacoecon Outcomes Res. 2013;13(6):735-41.

12. Vogler S, Zimmermann N, Ferrario A, Wirtz VJ, de Joncheere K, Pedersen HB, et al. Pharmaceutical policies in a crisis? Challenges and solutions identified at the PPRI Conference. J Pharm Policy Pract. 2016;9(1):1.

13. Espín J, Rovira J, Calleja A, Azzopardi-Muscat N, Richardson E, Palm W, et al. How can voluntary cross-border collaboration in public procurement improve access to health technologies in Europe? Policy Brief. 2016;21. https://www.eu2017.mt/ Documents/Programmes/PB21.pdf. Accessed 8 Apr 2017.

14. Vogler S, Habl C, Leopold C, Mazag J, Morak S, Zimmermann N. PHIS Hospital Pharma Report. Vienna: Pharmaceutical Health Information System (PHIS); commissioned by the European Commission and the Austrian Federal Ministry of Health; 2010. http://whocc.goeg.at/Literaturliste/Dokumente/BooksReports/ PHIS_HospitalPharma_Report.pdf. Accessed 2 April 2017.

15. Vogler S, Zimmermann N, Leopold C, Habl C, Mazag J. Discounts and rebates granted for medicines for hospital use in five European countries. Open Pharmacoecon Health Econ J. 2013;5:1-10.

16. van Harten WH, Wind A, de Paoli P, Saghatchian M, Oberst S. Actual costs of cancer drugs in 15 European countries. Lancet Oncol. 2016;17(1):18-20.

17. Morgan S, Vogler S, Wagner AK. Payers' experiences with confidential pharmaceutical price discounts: a survey of public and statutory health systems in North America, Europe, and Australasia. Health Policy. 2017;121(4):354-62. 